PROBLEMS

OF EDUCATION

IN THE $21^{\text {st }}$ CENTURY

Vol. 79 , No. 6, 2021

\section{${ }^{912}$ THE ROLE OF ACADEMIC FLOW IN STUDENTS' ACHIEVEMENT AND WELL-BEING}

\author{
Diana Olcar, Tajana Ljubin Golub, Majda Rijavec \\ University of Zagreb, Croatia \\ E-mail: diana.olcar@ufzg.hr, tajana.ljubingolub@ufzg.hr, majda.rijavec@ufzg.hr
}

\begin{abstract}
Flow experience is related to well-being. Still, the question arises as to whether the flow is beneficial because of its intensity and frequency, or its contribution to well-being depends on the domain in which it is experienced. It was hypothesized that flow experienced in a domain that is perceived important and useful (i.e., the academic domain) contributes more to students' well-being than flow experienced in domains that are perceived as less important and less useful (leisure and routine activities) even though it is in academic domain experienced less often and less intensely. This hypothesis was tested in two separate studies. In the first study, the flow was operationalized as a trait and the frequency of flow was measured via questionnaires. In the second study, the flow was operationalized as a state and the intensity of flow was measured via the experience sampling method. The samples were comprised of university students from Zagreb, Croatia. Both studies showed that flow in a domain that is perceived as more important and useful (i.e., the academic domain), although is experienced less often and less strongly, is more related to students' well-being than flow in domains perceived by students as less important and less useful (leisure and routine activities). It was also tested if the association between academic flow and well-being is mediated by academic achievement. This hypothesis was not accepted. The results of this study indicate that it is important for students to have opportunities to experience flow in their studies because it is a pleasant state, related to better achievement, and it adds to their overall well-being.

Keywords: flow experience, sampling method, flourishing, flow in learning, life satisfaction, optimal experience
\end{abstract}

\title{
General Introduction
}

Flow is a concept coined by Csikszentmihalyi (1975/2000) in the 1960s and 1970s who tried to understand what makes people work hard for long periods without any visible reward. For example, the artists he interviewed by the researcher would work passionately on some piece for long periods, just to abandon it when they thought they were finished and then focused with the same amount of energy on a new project. What happens is, Csikszentmihalyi concluded, that during the process of making art, artists are in a pleasurable state of flow, which they seek to attain again and again. Csikszentmihalyi (1975/2000) defined flow as a state of complete absorption in the activity for the sake of the activity itself. Flow usually occurs when concentration is high, skills and challenges are both high and in balance, when the goals are clear, and when there is immediate and unambiguous feedback (Csikszentmihalyi et al., 2005; Fong et al., 2014; Moneta, 2012). When these conditions are met, a person can achieve a flow state which is characterized by a sense of control, a merging of action and awareness, a loss of self-consciousness, and a loss of sense of time (Csikszentmihalyi (1975/2000). Activities that produce flow are autotelic or self-rewarding. In other words, a person is not doing the activity for some external reward but because they enjoy the activity itself.

Flow is a pleasant experience and has even been described as something that "makes life worth living" (Csikszentmihalyi \& Csikszentmihalyi, 2006). As a momentary state, it is 
characterized by feelings of enjoyment and positive affect (Asakawa, 2010; Csikszentmihalyi, 1997; de Manzano et al., 2010) and in the long run it is connected to higher life satisfaction (Olčar et al., 2019; Rijavec et al., 2016), higher psychological well-being (Asakawa, 2010; Rijavec et al., 2017; Rijavec et al., 2016) and the better satisfaction of basic psychological needs (Olčar, 2015). Experiencing flow is also negatively related to indicators of ill-being, such as general anxiety (Asakawa, 2010), performance anxiety (Fullagar et al., 2013), depressive symptoms (Mosing et al., 2018), and burnout (Mosing et al., 2018; Olčar, 2015; Rijavec et al., 2017; Ljubin-Golub et al., 2020). It is also related to higher performance, both in work (Salanova et al., 2006) and in the academic domain (Rijavec et al., 2016; 2017; Sumaya \& Darling, 2018), but also in sports (Bakker et al., 2011) and the arts (Butković et al., 2015; Csikszentmihalyi, 1975/2000). In other words, flow is a state that is momentarily pleasant, and related to long-term beneficial consequences.

The flow state is not exclusive to artists or special kinds of activities. Although flow research started with activities that are usually associated with leisure, later research showed that flow experiences also happen during obligatory activities, such as work (Csikszentmihalyi \& LeFevre, 1989; LeFevre, 1988) and studying (Carli et al., 1988; Massimini \& Carli, 1988; Rijavec et al., 2016). In an academic setting, flow is related to higher commitment, motivation, achievement, and persistence (Ljubin Golub et al. 2016; Shernoff et al., 2003; Shernoff \& Hoogstra, 2001; Shernoff \& Schmidt, 2008) and to a better understanding of the presented material (Culbertson et al., 2015). However, previous research has shown that flow during academic work is less frequent than flow during leisure activities. In one study (Rijavec et al., 2016), students' flow during non-academic activities was experienced frequently or always by the majority of students, while flow in any academic-related activities was experienced occasionally. Flow in the academic domain was most frequent during the preparation for various obligatory tasks, followed by flow experienced during seminars and in preparation for exams, and occurred least frequently while attending lectures (Rijavec et al., 2016). Similarly, in the study with Italian adolescents, the majority of flow-like states were experienced during leisure (52\%), followed by studying and classwork (34\%) and routine activities (13\%) (Massimini \& Carli, 1988).

Especially interesting is the finding that experiencing flow while studying is most relevant for students' well-being (Rijavec et al., 2016; Rijavec \& Ljubin Golub, 2018). Studies using questionnaires showed that, although flow during academic activities is less frequent than flow during activities in other domains (leisure and routine activities), it is more related to students' well-being than flow experienced in other domains such as leisure (Rijavec et al., 2016; Rijavec et al., 2017). It was hypothesized that flow during learning contributes more to well-being than flow experienced in other areas of life because students perceive academic activities as more important and more useful for their long term goals (Rijavec et al., 2017). Probably it is because spending time in an activity that person finds important and useful will contribute to their skills in that area. Also, having skills for areas of life that one finds useful and important can contribute to the quality of our life.

Flow has been conceptualized both as a trait and a state. Csikszentmihalyi (1997, p. 117) wrote about autotelic personality that "generally does things for their own sake, rather than in order to achieve some later external goal" suggesting that flow is a trait. In other words, some individuals are more prone to experience flow than others (often referred to as flow proneness). However, flow can also be, and very often is, operationalized as a state (Fong et al., 2014; Fullagar et al., 2013; Ullén et al., 2010).

Therefore, in order to gain deeper understanding of flow in learning as trait as well as state for students' well-being, two studies were conducted in the present research, each with a different conceptualization of flow, sample and method. In Study 1 flow was assessed as a trait using a questionnaire, and it was conducted to corroborate previous findings on the relationship 
PROBLEMS

OF EDUCATION

IN THE $21^{\text {st }}$ CENTURY

Vol. 79, No. 6,2021

914

between flow and well-being (Rijavec et al., 2017) on a new sample. In addition to previous research, Study 1 tested the mediation role of academic achievement in the relationship between academic flow and well-being. Study 2 was done in order to explore whether previous findings on the relationship between flow assessed as trait and well-being (Rijavec et al., 2017) are also valid at flow state level. In other words, study 2 was done in order to explore the association between flow state experienced in various life domains and students' momentary wellbeing. In Study 2 flow was assessed as a state and, using the gold standard for assessing flow experience, the experience sample method (ESM) (Hektner et al., 2007).

\section{STUDY 1}

The first aim of the Study 1 was to research experiences of flow in different life activities and to test the association between the usefulness and importance of the activity in which flow is experienced and the level of students' well-being. In line with previous research (Rijavec et al., 2016; Rijavec et al., 2017), it was hypothesized that flow will be experienced most frequently in leisure and least frequently during academic activities (Hypothesis 1). Also based on previous research founding that flow in activities that students find more useful and important contributed more to their well-being (Rijavec et al., 2017), it was hypothesized that the most important and useful domain would also be the one most related to well-being (Hypothesis 2).

The second aim was to explore whether a positive relationship between academic flow and well-being is mediated by academic achievement. Namely, previous research showed that the frequent experience of flow in academic areas is related to higher academic achievement (Rijavec et al., 2016) and that academic achievement is positively related to well-being (El Ansari \& Stock, 2010; Gilman \& Huebner, 2003; Verkuyten \& Thijs, 2002). It was assumed that academic achievement mediates relationship between flow in academic domain and wellbeing (Hypothesis 3).

Study 1 hypotheses: activities

Hypothesis 1: Flow occurs most frequently in leisure and least frequently during academic

Hypothesis 2: The strongest association between flow and well-being is in domain that is perceived as the most useful and important

Hypothesis 3: The relationship between flow in academic activities and well-being is mediated by academic achievement

\section{Research Methodology}

\section{General Background}

Study 1 is of correlational type, with flow experiences in various domains as predictors and indexes of well-being as criteria (life satisfaction and flourishing). Flow proneness was assessed with questionnaire. Academic achievement was used as a mediation variable.

\section{Sample}

The sample consisted of 267 undergraduates from the University of Zagreb. Participants were mostly female $(87 \%)$ with an age range from 17 to $27(\mathrm{M}=19.78, \mathrm{SD}=1.45)$. 


\section{Instrument and Procedures}

Flow proneness in different domains was measured with an adapted version of the "Swedish Flow Proneness Questionnaire" (SFPQ; Ullen et al., 2012; Ljubin-Golub et al., 2018). The original SFPQ consists of three subscales that measure proneness for flow experiences at work, during leisure, and during household maintenance with seven items for each subscale. For the purpose of this study, the work subscale was replaced with a subscale for assessing flow experienced during academic activities. This subscale was also used in our previous work and was proved to have good psychometric characteristics (Ljubin-Golub et al., 2018). An example of an item in the SFPQ academic domain subscale is: "When you do something for your studies, how often does it happen that you feel... fully focused?". Participants rated each item ranging from 1 (never) to 5 (every day). Mean scores were derived for each subscale. In this study, Cronbach's alpha coefficients of reliability were .79 for flow during academic activities, .77 for flow during maintenance activities, and .84 for flow during leisure.

The importance of activities was measured with one item for each life domain. Participants were asked to rate the importance of their studying, leisure activities, or household maintenance on a scale from 1 (completely unimportant) to 7 (extremely important).

The usefulness of activities was measured with one item for each life domain. Participants were asked to rate the usefulness of their studying, leisure activities, or household maintenance on a scale from 1 (completely non useful) to 7 (extremely useful).

Well-being was assessed with two indicators.

Life satisfaction was assessed with the "Satisfaction with Life Scale" (SWLS; Diener et al., 1985). This 5-item scale measures the cognitive component of subjective well-being. (e.g., The conditions of my life are excellent). Participants rated each item on seven-point Likert scales from 1 (strongly disagree) through 7 (strongly agree). Higher points indicate greater life satisfaction. Previous studies on Croatian samples showed adequate psychometric characteristics (e.g., Brdar, 2006; Rijavec et al., 2016). Cronbach's alpha reliability coefficient for the scale in this study was .80 .

Flourishing was assessed with the "Flourishing Scale" (FS; Diener et al., 2010). It is an 8 -item measure of positive human functioning. Items assess perceived success in important areas such as competence, engagement with daily activities, meaning and purpose in life, positive relationships, and optimism (e.g., I lead purposeful and meaningful life). Participants rated items on a 7-point scale, ranging from 1 (strongly disagree) to 7 (strongly agree). Higher points indicate greater flourishing. FS showed adequate psychometric characteristics and is strongly associated with other psychological well-being scales (Diener et al., 2009). Previous studies on Croatian samples showed adequate psychometric characteristics (Rijavec et al., 2016). Cronbach's alpha coefficient of reliability in the present study was .88 .

Academic achievement was measured with a self-reported grade point average (GPA) at the end of the previous semester. The GPA in Croatia ranges from 1 (indicating failure) to 5 (indicating excellent performance).

Questionnaires were administered in group settings during regular psychology lectures. Approximately 15 minutes were needed to fill out the questionnaires. Participation was voluntary, anonymous and no credit was assigned to it.

\section{Data Analysis}

Before analysis, the data were screened with respect to missing data and extreme values. Missing data were replaced with the arithmetic mean of the subscale. Results suggest that the data distributions were acceptable for further analysis. 
PROBLEMS

OF EDUCATION

IN THE $21^{\text {st }}$ CENTURY Vol. 79, No. 6, 2021

916

\section{Research Results}

Table 1 presents the descriptive statistics and correlations between variables. It can be seen that scores of flow in different life domains are positively correlated. Flourishing and life satisfaction correlate positively with flow in different activities and with the importance of different activities. Flourishing correlates positively with the usefulness of all activities, and life satisfaction only with the usefulness of leisure activities. Academic achievement correlates positively only with flow in academic activities and with the importance and usefulness of routine activities.

\section{Table 1}

Descriptive Statistics and Correlations between Flow in Different Activities, the Importance and Usefulness of Activities and Two Types of Well-being

\begin{tabular}{|c|c|c|c|c|c|c|c|c|c|c|c|c|c|}
\hline & & 1 & 2 & 3 & 4 & 5 & 6 & 7 & 8 & 9 & 10 & 11 & 12 \\
\hline \multirow{3}{*}{$\begin{array}{l}\vdots \\
. \leq \\
z \\
\text { ó } \\
\end{array}$} & $\begin{array}{l}\text { 1. Academic } \\
\text { activities }\end{array}$ & - & $.30 *$ & $.30^{* *}$ & $.30^{* *}$ & .12 & .09 & $.26^{* *}$ & .07 & $.13^{*}$ & $.43^{*+}$ & $.47^{* *}$ & $.23^{* *}$ \\
\hline & $\begin{array}{l}\text { 2. Routine } \\
\text { activities }\end{array}$ & & - & $.31^{* *}$ & $.12^{*}$ & $.36^{* *}$ & .03 & .08 & $.29^{* *}$ & $.13^{*}$ & $.23^{* *}$ & $.25^{* *}$ & -.02 \\
\hline & 3. Leisure & & & - & 0.12 & .08 & $.32^{* *}$ & $.15^{*}$ & .05 & $.22^{* *}$ & $.26^{* *}$ & $.35^{* *}$ & .09 \\
\hline \multirow{3}{*}{ 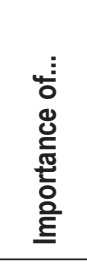 } & $\begin{array}{l}\text { 4. Academic } \\
\text { activities }\end{array}$ & & & & - & $.24^{* *}$ & .03 & $.43^{* *}$ & .09 & .02 & $.16^{* *}$ & $.24^{* *}$ & .10 \\
\hline & $\begin{array}{l}\text { 5. Routine } \\
\text { activities }\end{array}$ & & & & & - & $.15^{*}$ & $.14^{*}$ & $.50^{* *}$ & $.26 *$ & $.18^{* *}$ & $.28^{* *}$ & $.18^{*}$ \\
\hline & $\begin{array}{l}\text { 6. Leisure } \\
\text { activities }\end{array}$ & & & & & & - & .02 & .10 & $.57^{* *}$ & $.22^{* *}$ & $.23^{* *}$ & .07 \\
\hline \multirow{3}{*}{ 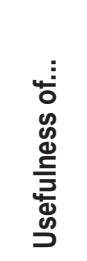 } & $\begin{array}{l}\text { 7. Academic } \\
\text { activities }\end{array}$ & & & & & & & - & .12 & .00 & .12 & $.20^{* *}$ & .02 \\
\hline & $\begin{array}{l}\text { 8. Routine } \\
\text { activities }\end{array}$ & & & & & & & & - & $.34^{* *}$ & .09 & $.27^{* *}$ & $.20^{*}$ \\
\hline & $\begin{array}{l}\text { 9. Leisure } \\
\text { activities }\end{array}$ & & & & & & & & & - & $.31^{* *}$ & $.43^{* *}$ & .04 \\
\hline \multirow{6}{*}{ 㐫 } & $\begin{array}{l}\text { 10. Life } \\
\text { satisfaction }\end{array}$ & & & & & & & & & & - & $.68^{* *}$ & .08 \\
\hline & 11. Flourishing & & & & & & & & & & & - & .01 \\
\hline & $\begin{array}{l}\text { 12. Academic } \\
\text { achievement }\end{array}$ & & & & & & & & & & & & - \\
\hline & $\mathrm{M}$ & 3.65 & 3.90 & 4.37 & 6.62 & 4.78 & 5.84 & 6.73 & 5.23 & 5.64 & 3.70 & 6.64 & 3.57 \\
\hline & SD & 0.57 & 0.63 & 0.57 & 0.59 & 1.43 & 1.01 & 0.56 & 1.49 & 1.20 & 0.76 & 0.94 & 0.59 \\
\hline & Rank & 3 & 2 & 1 & 1 & 3 & 2 & 1 & 3 & 2 & - & - & - \\
\hline
\end{tabular}

In order to assess in which life area students experience flow most frequently, a repeated measures ANOVA was performed. The results indicated that there was a difference in the frequency of flow experience in various domains $(F(2 / 520)=144.78 ; p<.001)$. Post hoc comparisons using the Bonferroni adjustment indicated that students experienced flow most frequently during leisure $(M=4.37, S D=0.57)$, followed by in routine activities $(M=3.90$, $S D=0.63)$, while flow during academic activities was the least frequent $(M=3.65, S D=0.57)$. Thus, the results were in line with hypothesis 1 . 
Table 2

Comparison of Correlation Coefficients between Flow in Different Domains and Well-being Variables with Meng's Test for Heterogeneity and Planned Contrasts

\begin{tabular}{|c|c|c|c|c|}
\hline & & & Z-test & $p$ (one tailed) \\
\hline & \multicolumn{4}{|c|}{ Dependent variable: Life satisfaction } \\
\hline & \multicolumn{4}{|c|}{$X^{2}(2)=14.47, p=.002$} \\
\hline \multirow{5}{*}{ 은 $\vdots$} & Academic activities & Routine activities + Leisure activities & 3.27 & .001 \\
\hline & Routine activities & Leisure activities & 1.94 & .030 \\
\hline & \multicolumn{4}{|c|}{ Dependent variable: Flourishing } \\
\hline & \multicolumn{4}{|c|}{$X^{2}(2)=14.15, p=.003$} \\
\hline & Academic activities & Routine activities + Leisure activities & 3.23 & .001 \\
\hline 은 & Routine activities & Leisure activities & 1.91 & .030 \\
\hline
\end{tabular}

According to hypothesis 2, the strongest relationship between flow and well-being is in domain that is perceived as the most useful and important. To test this hypothesis, correlation coefficients between flow and well-being (life satisfaction and flourishing) in different domains were compared. Meng's test for the heterogeneity of a set of correlated correlation coefficients (Meng et al., 1992) was performed. The results presented in Table 2 show that experiencing flow in some domains of life is more related to life satisfaction $\left(\chi^{2}(2)=14.47, p=.002\right)$ than in others. Planned contrasts demonstrate that flow in academic activities correlated significantly more highly with life satisfaction than flow in routine and leisure activities, and flow in leisure activities correlated significantly more highly with life satisfaction than flow in routine activities. When the relationship between flow in different life domains and flourishing was examined, it is evident again that flow experienced in some domains was more related to flourishing $\left(\chi^{2}(2)=\right.$ $14.15, p=.003$ ) than in others. Again, planned contrasts showed that flow in academic activities correlated most strongly with flourishing, and flow in leisure activities correlated more strongly with flourishing than flow in routine activities.

Next, the importance and usefulness of activities in different domains was examined. In order to assess which life area students find most important, repeated measures ANOVA was performed. The results indicate that students find some life domains more important than others $(F(2 / 520)=217.38 ; p<.00)$. Post hoc comparisons using Bonferroni adjustment indicated that students find academic activities the most important $(M=6.63, S D=0.66)$, followed by leisure activities $(M=5.84, S D=1.14)$, while routine activities are perceived as the least important $(M=4.78, S D=1.43)$. It was also shown that students found some life domains more useful than others $(F(2 / 532)=142.21 ; p<0.00)$. Post hoc comparisons using Bonferroni adjustment indicated that students found academic activities the most useful $(M=6.73, S D=0.56)$, followed by leisure activities $(M=5.64, S D=1.20)$, while routine activities were perceived as the least useful $(M=5.23, S D=1.49)$. Taken together, the results showed that academic domain was perceived as the most important and useful domain and that flow in the academic domain has the strongest relationship with well-being indices. Thus, the results are in line with hypothesis 2 .

Next, the assumption that the association between flow in academic activities and wellbeing is mediated by academic achievement was tested (Hypothesis 3). The results did not confirm this hypothesis. There was a direct effect of flow in academic activities on life satisfaction $(b=0.09, p=.001)$ and a significant direct effect of flow in academic activities on academic 
PROBLEMS

OF EDUCATION IN THE $21^{\text {st }}$ CENTURY Vol. 79, No. 6,2021

918

achievement $(b=0.03, p=.007)$. On the other hand, the effect of academic achievement on life satisfaction was not statistically significant $(b=-0.05, p=.63)$ and the indirect effect of flow in academic activities on life satisfaction through academic achievement was also not significant $(b=-0.002,95 \% C I[-0.01-0.01])$. Mediation was also tested with flourishing as a dependent variable, and the results were similar as in the previous analysis $(b=-0.007,95 \% C I[-0.02-$ $0.01]$ ). Thus, the mediating role of academic achievement was not found, but only the direct effect of flow in academic activities on academic achievement and also direct effect of flow on both indices of well-being.

\section{Discussion}

The results obtained in Study 1 showed that students experienced flow the least often in academic activities, followed by routine activities, and the most in leisure activities. This is in line with our previous findings (Rijavec et al., 2016; Rijavec et al., 2017). To experience flow in some domain, a person has to have skills that are appropriate for the level of the challenges in that domain. To experience flow repeatedly the challenges and the individual's skills have to grow proportionally (Csikszentmihalyi et al., 2005; Fong et al., 2014; Moneta, 2012). In leisure, a person usually has more freedom to choose activities that are in line with his or her skills level. A person who enjoys knitting will knit increasingly complex garments, and a person who enjoys skateboarding will choose more and more complex routes. Therefore, students have the opportunity to experience flow in leisure more often. Unfortunately, while studying, students usually cannot choose material that is more in line with their interests and more appropriate to their skill level. They are set with the same material which is for some more difficult to digest than for others. This leads to some students experiencing flow in the academic domain less often than others.

Additionally, it was hypothesized that the more important the life domain is for the students, the stronger the relationship between flow and students' well-being will be. Academic activities, which students find the most important and most useful, are related most to students' flourishing and life satisfaction. Flow in routine activities, which are perceived as the least important and least useful of the three examined domains, contribute the least to students' wellbeing.

The third hypothesis was that the relationship between flow in academic activities and well-being is mediated by academic achievement. In other words, it was hypothesized that experiencing flow in the academic domain more often builds up skills, which is evident in a higher GPA which then leads to higher student well-being. However, the results did not confirm this hypothesis. Although flow in academic activities was related both to a higher GPA and to higher well-being, the students' GPA and well-being were not related, and thus mediation effect of GPA was not found. Some previous studies found a positive correlation between students' GPA and well-being (El Ansari \& Stock, 2010; Gilman \& Huebner, 2003; Verkuyten \& Thijs, 2002), but this study failed to confirm these findings. In our study there is a direct relationship between experiencing flow in academic activities and well-being. It may be that students experience more positive emotions during learning while experiencing flow, and these positive emotions lead to higher well-being. Besides emotions as a potential mediating mechanism between academic flow and well-being, it may well be that there are also some other mediating mechanisms that should be explored in future studies.

\section{STUDY 2}

The aim of the Study 2 was to examine the association of flow operationalized as a state, i.e., intensity of flow at the moment and well-being at the same moment. As already stated, flow 
may be assessed not only as a trait but also as a state (Fullagar et al., 2013; Olčar, 2019; Ullén et al., 2010). Previous studies have shown a positive relationship between flow in learning and well-being when the flow was measured as a trait (Asakawa, 2010; Rijavec et al., 2016), but there is a lack of research on flow measured as a state and how it is related to well-being. Measuring flow as a state with the ESM method is considered a gold standard for measuring flow since there is no delay between experiences and reporting these experiences (Hektner et al., 2007). ESM gathers information at the present moment or shortly thereafter. Earlier studies showed there can be differences between emotions and behaviors reported in retrospective ratings and in those assessed in real time (Barrett, 1997; Schimmack, 2003). In retrospective ratings, individuals more often report experiences that occurred more recently, that are more personally relevant, that are consistent with the mood in which they are in, or that are unusual to them (Ebner-Priemer \& Trull, 2009). Methods such as ESM assess experiences in real time which add to the accuracy, generalizability and ecological validity of the data (Hektner et al., 2007).

Based on the previous findings that flow as a trait is most frequently experienced in leisure activities and less frequently experienced in academic activities, it was hypothesized that flow measured as a state using ESM method will be also most intensely experienced during leisure (Hypothesis 4). Based on previous research showing that experiencing flow in academic activities is more strongly related to students' well-being than experiencing flow in other life domains (Rijavec et al., 2017), it was hypothesized that the same is true at flow state level. In other words, it was hypothesized that the relationship of flow with momentary happiness and momentary satisfaction was the strongest during learning and the weakest during routine activities (Hypothesis 5). Both the previous research (Rijavec et al., 2017) and the results of the Study 1 have shown that tendency to experience flow domain that is perceived as more important and useful, i.e., studying contributes more to students' well-being than the flow experienced in domains perceived as less important and useful. In the Study 2 we hypothesized that the flow state experienced in the domain perceived as more important and useful contributes more to momentary well-being (Hypothesis 6).

Study 2 hypotheses:

Hypothesis 4: Students experience the highest intensity of flow during leisure activities, followed by routine activities and learning

Hypothesis 5: The relationship of intensity of flow state with momentary happiness and momentary satisfaction is the strongest during learning and the weakest during routine activities

Hypothesis 6: A flow state experienced in a domain that is perceived as more important and useful contributes more to momentary well-being.

\section{Research Methodology}

\section{General Background}

Study 2 is of correlational type, with flow state experiences in various domains used as predictors and momentary well-being as criteria (momentary happiness and momentary satisfaction). Students assessed flow state with questionnaire and samples of flow were collected using ESM method.

\section{Sample}

The convenient sample consisted of 101 university students ( $82 \%$ female). The mean age of the participants was $20.82(\mathrm{SD}=1.85$; range $=19$ to 28$)$. The participants were students from the University of Zagreb, Faculty of Science (76\%), and students from the Catholic University of Croatia, Department of Psychology (24\%). 
PROBLEMS

OF EDUCATION

IN THE $21^{\text {st }}$ CENTURY Vol. 79, No. 6, 2021

920

\section{Instruments}

Flow state was assessed by first asking students to state what they were doing at the moment. Then, they were asked to rate this activity on the adapted version of the Swedish Flow Proneness Questionnaire (SFPQ; Ullen et al., 2012) which consists of seven items. An adaption was made in the instruction section in terms that all items referred to the activity students were doing at the moment. An example of an item in the SFPQ is: "When you were doing this specific activity, did you feel fully focused?" Participants rated each item on a scale ranging from 1 (not at all) to 5 (completely). In this study, Cronbach's alpha coefficients of reliability for SFPQ in a specific domain were .81 for academic activities, .76 for maintenance activities, and .83 for activities during leisure.

Momentary happiness ("How happy do you feel at the moment?") and momentary satisfaction ("How satisfied do you feel at the moment?") were assessed each with a single item. These items were rated on a Likert type scale ranging from 1 (not at all) to 5 (completely).

Students also rated the importance and usefulness of the activity they were doing at the moment they received signal:

The importance of the activity was assessed with one item. Participants were asked to rate how important they perceived the activity they were doing at the moment on a Likert type scale from 1 (completely unimportant) to 7 (extremely important).

The usefulness of the activity was assessed with one item for each life domain. Participants were asked to rate how useful they perceived the activity they were doing at the moment on a Likert type scale from 1 (completely not useful) to 7 (extremely useful).

\section{Procedure}

Participants were approached during regular psychology classes with an offer to be included in the experience sampling method (ESM) study on flow. ESM belongs to a broader category of intensive longitudinal methods (Bolger \& Laurenceau, 2013). It was developed in the 1970s to study human experience in real time and in an everyday context (Hektner et al., 2007; Larson, \& Csikszentmihalyi, 1983). Participants report on their experiences at the moment they happen or short afterwards. Usually, the participants are prompted by a signal in a fixed or variable schedule or after a predefined event (e.g., every time a person lights up a cigarette, he or she has to fill in a short questionnaire). Since information is collected in real time, the advantage of this method over other methods is its high ecological validity while limiting recall bias (Shiffman et al., 2008). By assessing experience while it is happening, the possibility of distorting the experience and giving socially acceptable answers is lower (Hektner et al., 2007). As subjects complete multiple assessments over time, this makes data suitable for inter-subject and intra-subject comparisons, and also makes the data more reliable. The disadvantage of ESM is that the respondents are not always able or willing to interrupt the activity they are doing to complete the questionnaire. A sample of situations may therefore be selected.

During six consecutive days, participants received signals via SMS on their mobile phones. The signals were sent randomly within four equally long segments of the day, between 9 am to $9 \mathrm{pm}$. The minimum gap between the signals was 90 minutes. The text message the students received contained a web link which directed them to a short mobile survey. The questionnaire that students filled in was always of the same content. Approximately 5 minutes were needed to complete the questionnaires. Participation in study was voluntary, anonymous, and small course credit was given to participants. 


\section{Data Analysis}

PROBLEMS OF EDUCATION IN THE $21^{\text {st }}$ CENTURY Vol. 79, No. 6, 2021 921

Because data collected by ESM include multiple observations in one person, data were analyzed using multilevel modeling (MLM). MLM was chosen because when data are nested (in this study within a person), multilevel modeling solves the multiple comparison problem. A total of 2,147 experiences samples were collected. The results show that there is about $26.9 \%$ variability in the flow state between students, $21.4 \%$ variability in momentary happiness, and $23.5 \%$ variability in momentary satisfaction between students, showing that the data are suitable for multilevel modeling.

\section{Research Results}

The results presented in Table 3 (Model 1) showed that students reported the highest momentary flow during leisure time and the lowest momentary flow during learning. Thus, hypothesis 4 was supported.

\section{Table 3}

Observed Means of Flow, Happiness and Satisfaction in Different Contexts and the Relationship between Flow and Happiness and Satisfaction in Different Contexts at the Momentary Level

\begin{tabular}{|c|c|c|c|c|}
\hline & \multirow{2}{*}{$\begin{array}{l}\text { All contexts } \\
\text { together }\end{array}$} & \multicolumn{3}{|c|}{ Domain of activity } \\
\hline & & Learning & Routine activities & Leisure \\
\hline Number of observations & 2147 & 882 & 815 & 450 \\
\hline \multicolumn{5}{|c|}{ Model 1: DV - state flow } \\
\hline Intercept & 5.29 & $5.07^{\star *}$ & $5.31^{* *}$ & $5.67^{* *}$ \\
\hline Standard error & 0.06 & 0.06 & 0.08 & 0.09 \\
\hline Confidence interval & & $4.97-5.16$ & $5.18-5.45$ & $5.53-5.82$ \\
\hline \multicolumn{5}{|c|}{ Model 2: DV - momentary happiness } \\
\hline Intercept & $4.90^{* *}$ & $4.61^{* *}$ & $5.02^{* *}$ & $5.28^{* *}$ \\
\hline Standard error & 0.07 & 0.09 & 0.09 & 0.10 \\
\hline Confidence interval & & $4.51-4.75$ & $4.88-5.17$ & $5.13-5.44$ \\
\hline \multicolumn{5}{|l|}{ Fixed effect } \\
\hline Flow & $0.67^{\star *}$ & $0.69^{* *}$ & $0.45^{\star *}$ & $0.54^{* *}$ \\
\hline Standard error & 0.03 & 0.04 & 0.04 & 0.06 \\
\hline Confidence interval & & $0.65-0.74$ & $0.38-0.52$ & $0.44-0.63$ \\
\hline \multicolumn{5}{|c|}{ Model 3: DV - momentary satisfaction } \\
\hline Intercept & $4.93^{* *}$ & $4.66^{* *}$ & $5.05^{\star *}$ & $5.27^{\star *}$ \\
\hline Standard error & 0.07 & 0.09 & 0.09 & 0.10 \\
\hline Confidence interval & & $4.52-4.80$ & $4.90-5.20$ & $5.11-5.43$ \\
\hline \multicolumn{5}{|l|}{ Fixed effect } \\
\hline Flow & $0.63^{* *}$ & $0.71^{* *}$ & $0.45^{\star *}$ & $0.55^{\star *}$ \\
\hline Standard error & 0.03 & 0.04 & 0.04 & 0.06 \\
\hline Confidence interval & & $0.64-0.79$ & $0.38-0.52$ & $0.45-0.65$ \\
\hline
\end{tabular}

Note: ${ }^{* *} p<.01$. DV - dependend variable. 
PROBLEMS

OF EDUCATION IN THE $21^{\text {st }}$ CENTURY Vol. 79, No. 6,2021

922

As it can be seen from confidence intervals, flow intensity during routine activities was not significantly different from the flow intensity during learning activities and the flow intensity during leisure. Next, MLM analyses were performed with momentary happiness and momentary satisfaction as criterion variables. The results of Model 2 and Model 3 showed that students experienced the highest level of momentary happiness and satisfaction during leisure and the lowest level of momentary happiness and satisfaction during learning fully supported the hypothesis 4 . The relationship of flow with momentary happiness and momentary satisfaction was the strongest during learning and the weakest during routine activities, thus supported hypothesis 5 .

Next, one-way ANOVA was performed to examine which activities students find most important and most useful. There was a significant difference in how useful students found activities $(F(2,2148)=144.47, p<.001)$. Planned contrast revealed that students found studying more useful than the other two domains $(t(1690.11)=-15.28, p<.001)$, and maintenance activities more useful than leisure activities $(t(880.66)=-9.86, p<.001)$. There was also a significant difference in how important students found activities $(F(2,2148)=116.09, p<.001)$. Students found studying more important than the other two domains $(t(1694.34)=-15.94, p<$ $.001)$, and maintenance activities more important than leisure activities $(t(893.05)=-9.86, p<$ .01 ). Taken both results of MLM and ANOVA, it can be concluded that flow state experienced in the domain that is perceived as more important and useful (i.e., studying) contributes more to momentary well-being than the flow state experienced in domains perceived as less important and useful (i.e., routine and leisure). Thus, hypothesis 6 was also supported.

\section{Discussion}

The results of the Study 2 using experience sample method showed that students experienced flow state most intensely in leisure activities, and least intensely in academic activities. It was also found that flow in academic activities was related to momentary wellbeing assessed as happiness and satisfaction to a greater extent than flow in other domains. Out of three assessed life domain activities, i.e., academic, maintenance and leisure activities, academic activities were perceived as the most important and useful activities.

These findings are in line with previous studies assessing flow frequency over time, i.e., flow proneness (Rijavec et al., 2016; Rijavec et al., 2017). It should be noted that the ESM used in Study 2 is a method which "captures daily life as it is" (Hektner et al. 2006; p. 6), and thus recollection bias is reduced by collecting data in real-time or shortly afterward. Also, data were collected at multiple points in time, so reliability is high, and questions were asked in real-time about real situations thus adding to ecological validity.

The results of multilevel modeling showed that $27 \%$ of variance of flow can be attributed to individual variance, i.e., to dispositional factors. The remaining $73 \%$ of variance (systematic and error) of flow is within-individual variance. This means that although some people are more prone to flow, flow behaves more as a state and less as a trait and varies considerably based on situational characteristics. This is in line with earlier findings (Fullagar \& Kelloway, 2009; Fullagar et al., 2013) and adds an important bit of information for better understanding of flow construct (Mischel, 1969).

\section{General Discussion}

Both Study 1 and Study 2 showed the importance of domain in which students experience flow. Flow experienced in a domain that is perceived useful and important, i.e., the academic domain for students, although experienced less often than in the other two measured domains, is more related to students' well-being. It is possible that academic domain is perceived as important 
and useful by students because it contributes to their life goal of getting academic education. Flow is a beneficial and pleasant state experienced in various domains (Csikszentmihalyi et al., 2005) and this research showed that it is more important in which domain flow is experienced than the frequency and intensity of flow experiences. Flow in activities that we find useful and important is more beneficial to us than flow experienced in domains that are perceived as less useful and less important. This is in line with Delle Faves' statement (2009, p. 286), "optimal experience does not automatically bring well-being and development. Its outcomes vary according to the features of the associated activities and their role within the value system of the individuals and their social environment". Spending time and energy on activities that are not of high value does not lead to a sense of fulfillment and satisfaction as does spending time on something that is perceived as highly valued. Students feel satisfaction because they know that they are working towards their long-term goals which are aligned with their value system.

Study 1 assessed the frequency of flow over time (flow proneness) and Study 2 assessed the intensity of flow at the moment (flow state). Flow as a state showed a similar pattern of association with wellbeing as compared to flow measured as a trait. Students who experienced the highest intensity of flow state also experienced the highest level of well-being measured at momentary level. Both studies showed similar results, and these results are in line with previous research (Rijavec et al., 2017).

The results of our studies presented in this paper are especially valuable since there are not many studies that tackle the relationship between flow frequency and flow intensity, and Keller and Landhäußer (2012, p. 57) argue that "the distinction between frequency and intensity of flow experiences is worthwhile to consider". Receiving similar results and pattern of associations in both studies contributes to this polemic.

The results of the ESM study showed that about $27 \%$ of variance of flow can be attributed to dispositional factors, suggesting that the flow state depends more on situational factors than on intraindividual dispositions. This finding points to the importance of creating an academic context which will facilitate academic flow. Such a context includes clear goals and feedback (Steele \& Fullagar, 2009), autonomy-supportive teachers (Ljubin-Golub et al., 2020), the satisfaction of basic psychological needs (Liu \& Flick, 2019), among other factors.

Next, it was found that the positive relationship between flow in academic activities and well-being is not mediated by academic achievement. This finding shows that flow experience leads directly to well-being, and this relationship is not mediated via higher academic achievement. This is in line with research showing that flow experience is a pleasant experience which makes the subject feel inherently good (de Manzano et al., 2010; Rogatko, 2009). If this is experienced often, then it leads to higher general well-being. Obviously, flow in the academic domain is related to positive psychological states which help students build psychological resilience and allow them to function at an optimal level. It contributes to overall well-being directly and not because it is related to some external achievement or reward.

This research has several limitations. Both studies are correlational and done at one point in time or a short period, so it should be noted that the direction of causal relationships can go both ways. In addition to that, both samples comprised mainly female students which makes it difficult to generalize to male students and other samples. All questionnaires were based on self-assessment and can be subjective.

\section{General Conclusions and Implications}

Flow experienced in a domain perceived to be important and useful, i.e., academic domain, contributes to the well-being more than flow experienced in domains perceived as less important and useful, such as routine and leisure activities, even though it is experienced more often or intensely. Teachers should be aware of this and give students opportunities for

\begin{tabular}{|l} 
PROBLEMS \\
OF EDUCATION \\
IN THE 21 $1^{\text {st }}$ CENTURY \\
Vol. 79, No. 6, 2021 \\
\hline 923
\end{tabular} 
Diana OLCAR, Tajana LJUBIN GOLUB, Majda RIJAVEC. The role of academic flow in students' achievement and well-being

PROBLEMS

OF EDUCATION

IN THE $21^{\text {st }}$ CENTURY

Vol. 79, No. 6,202

924

experiencing flow in academic activities, as flow experience is beneficial for the overall wellbeing of students. Furthermore, it was concluded that flow behaves more as a state than a trait and can be experienced by anyone, given the right circumstances. Finally, the relationship between academic flow and students' well-being is not mediated by academic achievement. Flow contributes to well-being directly, not through mediation by academic achievement. This means that even low achieving students can enjoy high level of well-being if they have opportunities for flow experience in their studies.

\section{Compliance with Ethical Standards}

\section{Funding}

The studies were supported by grant of University of Zagreb.

\section{Conflict of Interest}

On behalf of all authors, the corresponding author states that there is no conflict of interest.

\section{Data availability}

The datasets generated during and analyzed during the current study are available in the Open Science Framework repository, osf.io/2gkn7

\section{Ethical approval}

All procedures performed were in accordance with the ethical standards of the institutional and/or national research committee and with the 1964 Helsinki declaration and its later amendments or comparable ethical standards.

\section{Informed Consent}

Informed consent was obtained from all individual participants included in the study.

\section{References}

Asakawa, K. (2010). Flow experience, culture, and well-being: how do autotelic Japanese college student feel, behave, and think in their daily lives? Journal of Happiness Studies, 11, 205-223. https://doi.org/10.1007/s10902-008-9132-3

Bakker, A. B., Oerlemans, W., Demerouti, E., Slot, B. B., \& Ali, D. K. (2011). Flow and performance: A study among talented Dutch soccer players. Psychology of Sport and Exercise, 12(4), 442-450. https://doi.org/10.1016/j.psychsport.2011.02.003

Barrett, L. F. (1997). The relationships among momentary emotion experiences, personality descriptions, and retrospective ratings of emotion. Personality and Social Psychology Bulletin, 23(10), 1100 1110. https://doi.org/10.1177/01461672972310010

Bolger, N., \& Laurenceau, J. P. (2013). Intensive longitudinal methods: An introduction to diary and experience sampling research. Guilford Press.

Butković, A., Ullén, F., \& Mosing, M. A. (2015). Personality related traits as predictors of music practice: Underlying environmental and genetic influences. Personality and Individual Differences, 74, 133-138. https://doi.org/10.1016/j.paid.2014.10.006

Brdar, I. (2006). Životni ciljevi i dobrobit: Je li za sreću važno što želimo? Društvena istraživanja, 4-5(8485), 671-691. 
Carli, M., Fave, A. D., \& Massimini, F. (1988). The quality of experience in the flow channels: Comparison of Italian and US students. In M. Csikszentmihalyi \& I. S. Csikszentmihalyi (Ed.), Optimal experience: Psychological studies of flow in consciousness (pp. 288-306). Cambridge University Press.

Csikszentmihalyi, M. (1975/2000). Beyond boredom and anxiety: Experiencing flow in work and play (2nd ed.). Jossey Bass.

Csikszentmihalyi, M. (1997). Finding flow: The psychology of engagement with everyday life. HarperCollins.

Csikszentmihalyi, M., \& Csikszentmihalyi, I. (2006). A life worth living - Contributions to positive psychology. Oxford University Press.

Csikszentmihalyi, M., \& LeFevre, J. (1989). Optimal experience in work and leisure. Journal of Personality and Social Psychology, 56(5), 815-822.

Csikszentmihalyi, M., Abuhamdeh, S., \& Nakamura, J. (2005). Flow. In A. Elliot (Ed.), Handbook of competence and motivation (pp. 598-698). The Guilford Press.

Culbertson, S. S., Fullagar, C. J., Simmons, M. J., \& Zhu, M. (2015). Contagious flow: Antecedents and consequences of optimal experience in the classroom. Journal of Management Education, 39(3), 319-349. https://doi.org/10.1177/1052562914545336

de Manzano, Ö., Theorell, T., Harmat, L., \& Ullén, F. (2010). The psychophysiology of flow during piano playing. Emotion, 10(3), 301-311. https://doi.org/10.1037/a0018432

Delle Fave, A. (2009). Optimal experience and meaning: Which relationship? Psychological Topics, 18(2), 285-302.

Diener, E., Emmons, R. A., Larsen, R. J., \& Griffin, S. (1985). The Satisfaction with Life Scale. Journal of Personality Assessment, 49(1), 71-75. https://doi.org/10.1207/s15327752jpa4901_13

Diener, E., \& Scollon, C. (2003, October). Subjective well-being is desirable, but not the summum bonum [Paper presentation]. The University of Minnesota Interdisciplinary Workshop on Well-Being $\mathrm{u}$ Minneapolis, MN, USA.

Diener, E., Derrick, W., Tov, W., Kim-Prieto, C., Choi, D. W., Oishi, S., \& Biswas-Diener, R. (2010). New well-being measures: Short scales to assess flourishing and positive and negative feelings. Social Indicators Research, 97, 143-156. https://doi.org/10.1007/s11205-009-9493-y

Ebner-Priemer, U. W., \& Trull, T. J. (2009). Ecological momentary assessment of mood disorders and mood dysregulation. Psychological Assessment, 21(4), 463-475. https://doi.org/10.1037/a0017075.

El Ansari, W., \& Stock, C. (2010). Is the health and wellbeing of university students associated with their academic performance? Cross sectional findings from the United Kingdom. International Journal of Environmental Research and Public Health, 7(2), 509-527. doi:10.3390/ijerph7020509

Fong, C. J., Zaleski, D. J., \& Leach, J. K. (2015). The challenge-skill balance and antecedents of flow: A meta-analytic investigation. The Journal of Positive Psychology, 10(5), 425-446. https://doi.org/10.1080/17439760.2014.967799

Fullagar, C. J., \& Kelloway, E. K. (2009). Flow at work: An experience sampling approach. Journal of Occupational and Organizational Psychology, 82(3), 595-615. https://doi.org/10.1348/096317908X357903

Fullagar, C. J., Knight, P. A., \& Sovern, H. S. (2013). Challenge/skill balance, flow, and performance anxiety. Applied Psychology: An International Review 62(2), 236259. https://doi.org/10.1111/j.1464-0597.2012.00494.x

Gilman, R., \& Huebner, S. (2003). A review of life satisfaction research with children and adolescents. School Psychology Quarterly, 18(2), 192-205. https://doi.org/10.1521/scpq.18.2.192.21858

Hektner, J. M., Schmidt, J. A., \& Csikszentmihalyi, M. (2007). Experience sampling method: Measuring the quality of everyday life. Sage.

Keller, J., \& Landhäußer, A. (2012). The flow model revisited. In S. Engeser (Ed.), Advances in flow research (pp. 51-64). Springer. https://doi.org/10.1007/978-1-4614-2359-1_3

Larson, R., \& Csikszentmihalyi M. (1983). The experience sampling method. In H. T. Reis (Ed.), Naturalistic approaches to studying social interaction: New directions for methodology of social and behavioral science (Vol. 15, pp. 41 - 56). Jossey-Bass.

Liu, X., \& Flick, R. (2019). The relationship among psychological need satisfaction, class engagement, and academic performance: Evidence from China. Journal of Education for Business, 94(6), 408417. https://doi.org/10.1080/08832323.2018.1541855

$\mid$\begin{tabular}{l} 
PROBLEMS \\
OF EDUCATION \\
IN THE 21 $1^{\text {st }}$ CENTURY \\
Vol. 79, No. 6, 2021 \\
\hline 925
\end{tabular}

925 
Diana OLCAR, Tajana LJUBIN GOLUB, Majda RIJAVEC. The role of academic flow in students' achievement and well-being

PROBLEMS

OF EDUCATION IN THE $21^{\text {st }}$ CENTURY Vol. 79 , No. 6, 2021

926

LeFevre, J. (1988). Flow and the quality of experience during work and leisure. In M. Csikszentmihalyi \& I. Csikszentmihalyi (Eds.), Optimal experience: Psychological studies of flow in consciousness (pp. 307-318). Cambridge University Press.

Ljubin Golub, T., Rijavec, M., \& Olčar, D. (2016). The relationship between executive functions and flow in learning. Studia Psychologica, 58, 47-58. doi:10.21909/sp.2016.01.706

Ljubin-Golub, T., Rijavec, M., \& Jurčec, L. (2018). Flow in the academic domain: The role of perfectionism and engagement. The Asia-Pacific Education Researcher, 27(2), 99-107. https://doi.org/10.1007/s40299-018-0369-2

Ljubin-Golub, T., Rijavec, M., \& Olčar, D. (2020). Student flow and burnout: The role of teacher autonomy support and student autonomous motivation. Psychological Studies, 65, 145-156. https://doi.org/10.1007/s12646-019-00539-6

Massimini, F., \& Carli, M. (1988). The systematic assessment of flow in daily experience. In Csikszentmihalyi, M. \& Csikszentmihalyi, I. (Eds.), Optimal experience: Psychological studies of flow in consciousness (pp. 266-287). Cambridge University Press.

Meng, X., Rosenthal, R., \& Rubin, D. B. (1992). Comparing correlated correlation coefficients. Psychological Bulletin, 111(1), 172-175. https://doi.org/10.1037/0033-2909.111.1.172

Mischel, W. (1969). Continuity and change in personality. American Psychologist, 24(11), 10121018. https://doi.org/10.1037/h0028886

Moneta, G. B. (2012). On the measurement and conceptualization of flow. In C. Peifer C. \& S. Engeser (Eds.), Advances in flow research (pp. 23-50). Springer.

Mosing, M. A., Butković, A., \& Ullen, F. (2018). Can flow experiences be protective of work-related depressive symptoms and burnout? A genetically informative approach. Journal of Affective Disorders, 226, 6-11. https://doi.org/10.1016/j.jad.2017.09.017

Olčar, D. (2015). Teachers' life goals and well-being: Mediating role of basic psychological needs and flow (Unpublished doctoral dissertation). University of Zagreb, Zagreb, Croatia.

Olčar, D. (2019). Personality traits as predictors of domain specific flow proneness. The European Proceedings of Social \& Behavioral Sciences EpSBS, LXXII, 86-99. https://doi.org/10.15405/epsbs.2019.11.7

Olčar, D., Rijavec, M., \& Ljubin-Golub, T. (2019). Teachers' life satisfaction: The role of life goals, basic psychological needs and flow at work. Current Psychology, 38(2), 320329. https://doi.org/10.1007/s12144-017-9611-y

Rijavec, M., Ljubin Golub, T., \& Olčar, D. (2016). Can learning for exams make students happy? Facultyrelated and faculty-unrelated flow experiences and well-being. Croatian Journal of Education, 18(1), 153-164. https://dx.doi.org/10.15516/cje.v18i0.2223

Rijavec, M., Ljubin Golub, T., Jurčec, L., \& Olčar, D. (2017). Working part-time during studies: The role of flow in students' well-being and academic achievement. Croatian Journal of Education, 19(3), 157-175. https://doi.org/10.15516/cje.v19i0.2724

Rijavec, M., \& Ljubin Golub, T. (2018). Zanesenost u akademskim aktivnostima i dobrobit studenata. Psihologijske teme, 3, 519-541. https://doi.org/10.31820/pt.27.3.9

Rogatko, T. P. (2009). The influence of flow on positive affect in college students. Journal of Happiness Studies, 10(2), 133-148. https://doi.org/10.1007/s10902-007-9069-y

Salanova, M., Bakker, A. B., \& Llorens, S. (2006). Flow at work: Evidence for an upward spiral of personal and organizational resources. Journal of Happiness Studies, 7, 1-22. https://doi.org/10.1007/s10902-005-8854-8

Shernoff, D. J., \& Hoogstra, L. (2001). Continuing motivation beyond the high school classroom. New Directions for Child and Adolescent Development, 93, 73-88. https://doi.org/10.1002/cd.26

Shernoff, D. J., \& Schmidt, J. A. (2008). Further evidence of an engagement-achievement paradox among US high school students. Journal of Youth and Adolescence, 37(5), 564580. https://doi.org/10.1007/s10964-007-9241-z

Shernoff, D. J., Csikszentmihalyi, M., Schneider, B., \& Shernoff, E. S. (2003). Student engagement in high school classrooms from the perspective of flow theory. School Psychology Quarterly, 18(2), 158-176. https://doi.org/10.1521/scpq.18.2.158.21860

Shiffman, S., Stone, A. A., \& Hufford, M. R. (2008). Ecological momentary assessment. Annual Review of Clinical Psychology, 4, 1-32. https://doi.org/10.1146/annurev.clinpsy.3.022806.091415 
Schimmack, U. (2003). Affect measurement in experience sampling research. Journal of Happiness Studies, 4(1), 79-106. https://doi.org/10.1023/A:1023661322862

Steel, J. P., \& Fullagar, C. (2009). Facilitators and outcomes of student engagement in a college setting. The Journal of Psychology, 143(1), 5-27. https://doi.org/10.3200/JRLP.143.1.5-27

Sumaya, I. C., \& Darling, E. (2018). Procrastination, flow, and academic performance in real time using the experience sampling method. The Journal of Genetic Psychology, 179(3), 123-131. https://doi.org/10.1080/00221325.2018.1449097

Ullén, F., de Manzano, Ö., Theorell, T., \& Harmat, L. (2010). The physiology of effortless attention: Correlates of state flow and flow proneness. In B. Bruya (Ed.), Effortless attention: A new perspective in the cognitive science of attention and action (pp. 205-218). Bradford Books

Ullén, F., de Manzano, Ö., Almeida, R., Magnusson, P. K., Pedersen, N. L., Nakamura, J., Csikszentmihalyi, M., \& Madison, G. (2012). Proneness for psychological flow in everyday life: Associations with personality and intelligence. Personality and Individual Differences, 52(2), 167-172. https://doi.org/10.1016/j.paid.2011.10.003

Verkuyten, M., \& Thijs, J. (2002). School satisfaction of elementary school children: The role of performance, peer relations, ethnicity and gender. Social Indicators Research, 59(2), 203-228. https://doi.org/10.1023/A:1016279602893

Received: September 28, 2021

Accepted: December 04, 2021

\begin{tabular}{l} 
PROBLEMS \\
OF EDUCATION \\
IN THE 21 $1^{\text {st }}$ CENTURY \\
Vol. 79, No. 6, 2021 \\
\hline 927
\end{tabular} 